\title{
Awareness among Young Parents about Preventive Aspects of Early Childhood Caries in Abha City, Kingdom of Saudi Arabia
}

\author{
${ }^{1}$ Rafi Ahmad Togoo, ${ }^{2}$ Ibrahim Al-Shahrani, ${ }^{3}$ Wejdan Saad Al-Absi, ${ }^{4}$ Fatima Saeed Al-Shahrani \\ ${ }^{5}$ Amal Saeed Shiban Al-Shahrani, ${ }^{6}$ Mohammed Nadeem Ahmed Bijle
}

\begin{abstract}
Background: Early childhood caries (ECC) is a common disease affecting very young children in today's era. The prevention of ECC depends upon the vital information parents are available with during the upbringing of the child.
\end{abstract}

Aim: This survey was undertaken to evaluate the awareness among parents about preventive aspects of ECC in Abha City, Kingdom of Saudi Arabia.

Methodology: A questionnaire study was conducted among young parents about preventive aspects of ECC in Abha City, Kingdom of Saudi Arabia. Descriptive statistics was used to observe the awareness.

Results: A total of 157 parents participated in the study of which 126 were mothers and 31 fathers. The mean age of the parents participating in the study was 34 years, and $55 \%$ of the participants had education till the university level. About half $(53 \%)$ of the parents were unaware that the child should be taken for the first dental visit by 1 year of age. Around $60 \%$ of the participants had taken their children to the dentist only when the dental problem was in persistence and $48 \%$ of the participants allowed their child to sleep with milk bottle or juice in their mouth.

Conclusion: Hence, it can be concluded that the parents in Abha, KSA, are moderately aware of dental needs of their young children.

Keywords: Awareness, Dental caries, Early childhood caries, Knowledge, Saudi Arabia.

How to cite this article: Togoo RA, Al-Shahrani I, Al-Absi WS, Al-Shahrani FS, Al-Shahrani ASS, Bijle MNA. Awareness among Young Parents about Preventive Aspects of Early Childhood Caries in Abha City, Kingdom of Saudi Arabia. World J Dent 2016;7(1):10-13.

Source of support: Nil

Conflict of interest: None

${ }^{1}$ Professor, ${ }^{2,6}$ Assistant Professor, ${ }^{3-5}$ Intern

${ }^{1,2,6}$ Department of Pediatric Dentistry and Orthodontic Sciences College of Dentistry, King Khalid University, Abha, Saudi Arabia

${ }^{3-5}$ College of Dentistry, King Khalid University, Abha, Saudi Arabia

Corresponding Author: Mohammed Nadeem Ahmed Bijle Assistant Professor, Department of Pediatric Dentistry and Orthodontic Sciences, College of Dentistry, King Khalid University, Abha, Saudi Arabia, Phone: +966-504217533, e-mail: info@drnadeembijle.com

\section{INTRODUCTION}

Dental caries affects humans of all ages throughout the world and remains the major dental health problem among school children globally. Tooth decay has become epidemic among younger children. A rapid form of tooth decay, known as early childhood caries (ECC), is a widely spread disease faced by children and is on the rise. Research shows that ECC can cause lasting harm to a child's dental and systemic health, it also affects social and intellectual development. ${ }^{2}$

In 2003, the American Academy of Pediatric Dentistry defined ECC as 'the presence of one or more decayed (noncavitated or cavitated), missing (due to caries), or filled tooth surfaces in any primary tooth in a child up to 71 months of age or younger. ${ }^{3,4}$ The factors responsible for ECC are the presence of dental plaque, susceptible host, fermentable carbohydrate diet, a high number of cariogenic microorganisms and time factor. ${ }^{4,5}$

Early childhood caries is a common disease affecting very young children in today's era. In preschoolers, the prevalence of ECC ranges from 1 to $12 \%$ in developed countries and among high-risk group ranges from 50 to $80 \%{ }^{6-9}$ Early childhood caries has been associated with demographic characteristics, parental attitudes, educational status of mother, oral hygiene practices, frequent use of medications and parenting practice, feeding habits, maternal nutrition, psychosocial issues, temperament of the child, mouth breathing habit, pacifiers dipped in honey, socioeconomic status, siblings, children with longstanding illness or special health needs. ${ }^{9-13}$ The majority of children affected belong to low socioeconomic society, whereby they are less vulnerable to visit the specialist in the field. ${ }^{2,6,7,9,14}$ The other rationale could be detailed as being related to lack of knowledge by the guardians or caretakers regarding the disease. The conventional concept of nonsignificance related to primary teeth may be an add-on. In the bargain at least, it can be expected by the parents or caretakers to have primary familiarity regarding the preventive aspects of ECC if not complete understanding of the etiology. ${ }^{2}$

Hence, this survey was undertaken to evaluate the awareness among parents about preventive aspects of ECC in Abha City, Kingdom of Saudi Arabia. 


\section{MATERIALS AND METHODS}

The present study was conducted among young parents in Abha City, Kingdom of Saudi Arabia, to know about the awareness regarding preventive aspects of ECC. Written informed consent was obtained from all the participants and the ethical clearance for the study was obtained from the institutional review board. An eightitem closed-ended questionnaire concerning questions with preventive aspects of ECC was used for the study. The questionnaire was pilot tested on 20 respondents for internal validity (Cronbach's $\alpha=0.9$ ) to exclaim its acceptability for the proposed survey. The questionnaire comprised of general information questions related to family, general questions about teeth eruption and its respective age and preventive approaches for ECC. The data collected were entered into MS Excel 2013 (Microsoft Inc., USA) and thus subjected to statistical analysis with SPSS v 20 (IBM Statistics Inc., Chicago, USA). For the purpose of this study, only descriptive statistics was used to observe the awareness.

\section{RESULTS}

The response rate of the study was $100 \%$. Table 1 depicts the demographic details of the study participants. A total of 157 parents participated in the study of which 126 were mothers and 31 fathers. The mean age of the parents participating in the study was 34 years, and $55 \%$ of the participants had education till the university level. Around $27 \%$ of the participants had more than four children in their family and rest equally were divided in a number of 1, 2, 3 or 4 children within their family. About $40 \%$ of the population had children with age less than 2 years. Table 2 shows the responses of the study participants to the questions. More than half $(56 \%)$ of the parents responded that all primary teeth in a child erupt by approximately 2 years of age. It was also observed that around $53 \%$ of the parents were unaware that the child should be taken for the first dental visit by 1 year of age. Around $60 \%$ of the participants had taken their children to the dentist only when the dental problem was in persistence. Most (73\%) of the participants were aware of the child dentistry specialization with 97\% participants preferring a pedodontist in the case of dental problems with children. About half $(48 \%)$ of the participants allowed their child to sleep with milk bottle or juice in their mouth. The majority of participants monitored the brushing of children either regularly or irregularly. It was also encouraging to note that majority (83\%) of sample group was aware of preventive dentistry programs being conducted in their vicinity by dental health care providers. Chi-square test was used to check the association between educational statuses of the
Table 1: Demographic details of the respondents

\begin{tabular}{|c|c|c|}
\hline \multicolumn{3}{|c|}{ Distribution according to the gender } \\
\hline Gender & Number & Percentage \\
\hline Female & 126 & 80.3 \\
\hline Male & 31 & 19.7 \\
\hline Total & 157 & 100 \\
\hline \multicolumn{3}{|c|}{ Mean age of the study sample } \\
\hline Study sample & Mean & $S D$ \\
\hline Female & 33.06 & 5.945 \\
\hline Male & 35.52 & 5.802 \\
\hline Total & 33.55 & 5.979 \\
\hline \multicolumn{3}{|c|}{ Distribution according to education } \\
\hline Education & Number & Percentage \\
\hline Diploma & 12 & 7.6 \\
\hline High school & 41 & 26.1 \\
\hline Master & 3 & 1.9 \\
\hline Middle school & 8 & 5.1 \\
\hline None & 5 & 3.2 \\
\hline Primary school & 2 & 1.3 \\
\hline University & 86 & 54.8 \\
\hline Total & 157 & 100.0 \\
\hline \multicolumn{3}{|c|}{$\begin{array}{l}\text { Responses to what is the total } \\
\text { number of children in your family? }\end{array}$} \\
\hline Response & Number & Percentage \\
\hline 1 & 27 & 17.2 \\
\hline 2 & 29 & 18.5 \\
\hline 3 & 30 & 19.1 \\
\hline 4 & 29 & 18.5 \\
\hline More & 42 & 26.8 \\
\hline \multicolumn{3}{|c|}{$\begin{array}{l}\text { Responses to what is the age of } \\
\text { your youngest child? }\end{array}$} \\
\hline Response & Number & Percentage \\
\hline Less than 2 years & 63 & 40.1 \\
\hline Less than 3 years & 27 & 17.2 \\
\hline Less than 4 years & 20 & 12.7 \\
\hline Less than 5 years & 16 & 10.2 \\
\hline More than 5 years & 31 & 19.7 \\
\hline
\end{tabular}

parents with their responses to the questionnaire; no statistical significance was obtained.

\section{DISCUSSION}

Early childhood caries, or ECC, is a severe disease of the teeth of infants and toddlers. The condition first affects the primary maxillary incisors, and then involves the primary molars. ${ }^{15,16}$ In cases of ECC, oral health for preschoolers is commonly neglected. These children come from vulnerable population to caries because of their inability to communicate with their parents and dependence. ${ }^{9}$

There is a correlation between the education level of parents and severity of ECC in their children, in contrast no such correlation existed in the present study ${ }^{17-19}$ Lower prevalence of dental caries have been associated with higher levels of parental education. ${ }^{18}$ Milgrom stated mother's dental knowledge, behavior and general care of her child which are the factors that contribute to caries risk. ${ }^{20}$ 
Table 2: Responses of the study participants to the questionnaire

\begin{tabular}{|c|c|c|}
\hline Response & Number & Percentage \\
\hline \multicolumn{3}{|c|}{$\begin{array}{l}\text { Responses to approximately by which } \\
\text { age should a child have all its milk teeth erupted? }\end{array}$} \\
\hline By 2 years of age & 88 & 56.1 \\
\hline After 3 years of age & 60 & 38.2 \\
\hline State otherwise & 9 & 5.7 \\
\hline \multicolumn{3}{|c|}{$\begin{array}{l}\text { Responses to are you aware that } \\
\text { children should be taken for dental } \\
\text { examination in the first year of their life? }\end{array}$} \\
\hline Yes & 73 & 46.5 \\
\hline No & 84 & 53.5 \\
\hline \multicolumn{3}{|c|}{$\begin{array}{l}\text { Responses to when did you take } \\
\text { your child for routine dental examination? }\end{array}$} \\
\hline In the first year & 13 & 8.3 \\
\hline In the second year & 17 & 10.8 \\
\hline After 2 years of age & 33 & 21.0 \\
\hline Only in case of dental problem & 94 & 59.9 \\
\hline \multicolumn{3}{|c|}{$\begin{array}{l}\text { Responses to are you aware that } \\
\text { here is a specialist for children's dentistry }\end{array}$} \\
\hline Yes & 114 & 72.6 \\
\hline No & 43 & 27.4 \\
\hline \multicolumn{3}{|c|}{$\begin{array}{l}\text { Responses to will you prefer to take } \\
\text { your children to pediatric dental specialist in } \\
\text { case he/she is available in the dental facility }\end{array}$} \\
\hline Yes & 152 & 96.8 \\
\hline No & 5 & 3.2 \\
\hline \multicolumn{3}{|c|}{$\begin{array}{l}\text { Responses to do you put your child } \\
\text { to sleep with a bottle of milk or juice in his/her mouth? }\end{array}$} \\
\hline Yes always & 75 & 47.8 \\
\hline No never & 17 & 10.8 \\
\hline Infrequently & 65 & 41.4 \\
\hline \multicolumn{3}{|c|}{$\begin{array}{l}\text { Responses to do you monitor } \\
\text { the brushing of your youngest child }\end{array}$} \\
\hline Yes & 71 & 45.2 \\
\hline No & 18 & 11.5 \\
\hline Sometimes & 68 & 43.3 \\
\hline \multicolumn{3}{|c|}{$\begin{array}{l}\text { Responses to are you aware of the preventive dentistry } \\
\text { programs being organized by dental institutions in your city? } \\
\text { (MOH, KKUCOD, private dental clinics) }\end{array}$} \\
\hline Yes & 27 & 17.2 \\
\hline No & 130 & 82.8 \\
\hline
\end{tabular}

Bottle-feeding, especially during the night, when children sleep with a bottle in their mouth, has been considered cariogenic. ${ }^{17} \mathrm{Du}$ et $\mathrm{al}^{21}$ found that children who had been bottle-fed had five times greater risk of having ECC compared to children who were breastfed.

Early childhood caries is preventable. The education of parents on good oral hygiene and dietary practices, use of fluoride and noncariogenic sweeteners is imperative for avoiding the psychological, physical, and economic consequences of ECC. ${ }^{17,22}$ Prevention of ECC should begin from pre- and the perinatal period for improvement in attitude and awareness of pregnant women. ${ }^{17,23}$

There are other preventive measures that can be also applied. The effect of fluoride in reducing caries is well documented, and it may be delivered either topically or systemically. The most common method for systematic fluoride is fluoridated drinking water, which is effective in reducing the severity of dental decay in population..$^{7,24}$ Other modalities, such as the administration of salt fluoridation or fluoride supplements (beverages, tablets, drops), can be utilized where water fluoridation is not possible. Supervised fluoride mouth-rinsing can result in the reduction in caries increment in children. ${ }^{25}$

Early childhood caries can be treated depending on: progression of the disease, age of the child, social, behavioral history and medical history of the child through various interventions. Examination of the child annually starting from his 1st birthday for prevention and intervention holds the key. ${ }^{26}$

Community-based solutions should be explored and used in conjunction with the existing and emerging strategies or promoting early childhood oral health and preventing dental decay. These strategies should include health education of mothers, promoting the first dental visit by 12 months, providing anticipatory guidance, suppression of maternal reservoirs of mutans streptococci, motivational interviewing (MI), self-examination for early signs of ECC, using chemotherapeutics, promote use of fluoridated dentifrice, water fluoridation, dietary counseling, and other methods whose simplicity, costeffectiveness, and feasibility is proven for communities. ${ }^{17,25}$ Appropriate parenting practices leading to behavioral change among parents, caregivers and the community are the need of the hour in the prevention of ECC. Community initiatives also have the potential to increase awareness regarding ECC. Children from lower socioeconomic status need to be targeted by public funded oral health programs, and effective strategies have to be developed to promote proper feeding habits. ${ }^{17,25}$

\section{CONCLUSION}

Hence, it can be concluded that the parents in Abha, KSA, are moderately aware of dental needs of their young children. However, a more concerted program outlining the necessary aspects of child oral health hygiene and maintenance with its emphasis on ECC is required for further prevention of diseases.

\section{REFERENCES}

1. World Health Organization (WHO). Global strategy for infant and young child feeding. Geneva. WHO 2003. Available at: http://www.who.int/nutrition/publications/gs_infant_ feeding_text_eng.pdf (Last Accessed on 23 Feb 2015).

2. Available at: http://www.aapd.org/aapd $\% E 2 \% 80 \% 99$ s_state_ of_little_teeth_report_an_examination_of_the_epidemic_ of_tooth_decay_among_our_youngest_children/ (Last Accessed on 23 Feb 2015). 
3. American Academy of Pediatric Dentistry. Reference manual 2002-03. Policies on early childhood caries; Unique challenges and treatment options. Pediatr Dent 2003;23:24-25.

4. Kuriakose S, Prasannan M, Remya KC, Kurian J, Sreejith KR. Prevalence of early childhood caries among preschool children in Trivandrum and its association with various risk factors. Contemp Clin Dent 2015;6(1):69-73.

5. Ripa LW. Nursing caries: a comprehensive review. Pediatr Dent 1988;10:268-282.

6. Reisine S, Douglass JM. Psychosocial and behavioral issues in early childhood caries. Community Dent Oral Epidemiol 1998;26:32-44.

7. Shaw L, Clark DC, Edger NP. The oral health status of Cree children living in Chisasibi, Quebec. J Can Dent Assoc 1987;53:201-205.

8. Hallett KB, O'RourkePK. Social and behavioural determinants of early childhood caries. Aust Dent J 2003;48:27-33.

9. Prakash P1, Subramaniam P, Durgesh BH, Konde S. Prevalence of early childhood caries and associated risk factors in preschool children of urban Bengaluru, India: a crosssectional study. Eur J Dent 2012;6(2):141-152.

10. Filho NE, Mayer MPA, Pontes P, Pignatari ACC. Caries prevalence, levels of mutans streptococci, and gingival and plaque indices in 3 to 5 -year-old mouth-breathing children. Caries Res 2004;38:572-575.

11. Perssini S. Pacifier use and early childhood caries. An evidence-based study of literature. J Can Dent Assoc 2003; 69:16-22.

12. Tinanoff N, O'Sullivan DM. Early childhood caries: overview and recent findings. Pediatr Dent 1997;19:12-15.

13. Wyne AH. Early childhood caries: nomenclature and case definition. Community Dent Oral Epidemiol 1999;27:313-315.

14. Albert RJ, Cantin RY, Cross HG, Castaldi CR. Nursing caries in the Inuit children of the Keewatin. J Can Dent Assoc 1988;54:751-758.

15. Weinstein P, Harrison R, Benton T. Motivating mothers to prevent caries: Confirming the beneficial effect of counseling. J Am Dent Assoc 2006;137:789-793.
16. Tinanoff N, O'Sullivan DM. The association of early dental caries patterns with caries incidence in preschool children. J Public Health Dent 1996;56(2):81-83.

17. Zafar S, Harnekar SY, Siddiqi A. Early childhood caries: etiology, clinical considerations, consequences and management. Int Dent SA 2009;11:24-36.

18. Al-Hosani E, Rugg-Gunn A. Combination of low parental educational attainment and high parental income related to high caries experience in pre-school children in Abu Dhabi. Community Dent Oral Epidemiol 1998;26:31-36.

19. Dini EL, Holt RD, Bedi R. Caries and its association with infant feeding and oral health-related behaviours in 3 to 4 year-old Brazilian children. Community Dent Oral Epidemiol 2000;28:241-248.

20. Milgrom P, Riedy CA, Weinstein P, Tanner ACR, Manibusan L, Bruss J. Dental caries and its relationship to bacteria infection, hypoplasia, diet and oral hygiene in 6 to 36 months old children Community Dent Oral Epidemiol 2000;28: 295-306.

21. Du M, Bian Z, Guo L, Holt R, Champion J, Bedi R. Caries patterns and their relationship to infant feeding and socioeconomic status in 2 to 4-year-old Chinese children. Int Dent J 2000;50(6):385-389.

22. Kowash MB, Pinfield A, Smith J, Curzon ME. Effectiveness on oral health of a long-term health education programme for mothers with young children. Br Dent J 2000;188:201-205.

23. Low W, Tan S, Schwartz S. The effect of severe caries on the quality of life in young children. Pediatr Dent 1999;21(6): 325-326.

24. Featherstone JD. The continuum of dental caries, evidence for a dynamic disease process. J Dent Res 2004;83 (Spec No C):C39-C42.

25. Davies GN. Early childhood caries-a synopsis. Community Dent Oral Epidemiol 1998;26:Suppl 1:106-16.

26. American Academy of Pediatric Dentistry. Policy on Early Childhood Caries (ECC): Classifications, Consequences, and PreventiveStrategies. AAPD Reference manual 2008/2009;30(7): 41-43. 